\title{
DE ZEVENDE ZITTING VAN HET INSTITUT INTERNATIONAL DE STATISTIQUE.
}

Toen in 1878, door de ontbiuding van de commission permanente du congrès international de statistique, - om redenen die in het paragraafje, dat billijkerwijze in de biographie van Bismarck gewijd moet worden aan zijne verhouding tot de statistiek, het best zullen kunnen worden verklaard en die hare nawerking nog thans doen gevoelen - deze internationale vereeniging ophield te bestaan, was het met zekerheid te zeggen dat in eeu of anderen vorm zij eerlang weder zou herleven. Op aanstichting van Quetelet, Engel en Heuschling in 1851 te Londen tot standgekomen, had zij in de negen zittingen die zij achtereenvolgess hield te Brussel (1853), Parijs (1855), Weenen (1857), Londen (18fi0), Berlijn (1863), Florence (1867), 's-Gravenhage (1869), St. Petersburg (1872), en Budapest (J876), ondanks de gebreken die haar, als alle groote congressen trouwens, aankleefden, zich vele en velerlei verdiensten verworven voor de ontwikkeling der statistiek en de internationale vergelijkbaarheid harer uitkomsten. De voordeelen van een geregeld persoonlijk verkeer tusschen de beoefenaars der statistiek waren te duidelijk an het licht getreden om te kunnen berusten in de ontbinding van het orgaan waardoor dit verkeer mogelijk was gemaakt. En toen in den zomer van 1885 twee feesten op statistisch gebied ter eere, eerst van het 25-jarig bestaan van de Société de statistique de Paris, later van het 50-jarig jubilé der Royal Statistical Society te Louden, de statistici der verschillende landen weder samen brachten, werd besloten een nieuwe internationale vereeniging te stichten, zoo veel mogelijk met vermijding der gebreken van hare voorgangster.

Een vrije vereeniging zou het zijn, tegenover de regeeringen wet geen ander gezag bekleed dan haar krachtens het wetenschappelijk gehalte harer leden toekwam. Hare be- 
sluiten zouden wenschen zijn, raadgevingen, niet aan de gouvernementen, maar aan de bureaux van statistiek, welker directeuren vrijelijk zouden beoordeelen in hoever hic et nunc de toepassing daarvan aanbeveling mocht verdienen. Het aantal leden zou beperkt blijven tot 100 , gekozen uit de eigenlijke vakmanuen, zij het dan ook uit de beide categoriën waarin Engel hen verdeelde: de voortbrengers en de verbruikers. Voorts zouden ten hoogste 100 membres associés kunnen worden benoemd, en een zeker aantal eereleden.

Op deze grondslagen $\mathrm{kwam}$ in $\mathbf{3 8 8 5}$ te Londen, dank zij vooral de ijverige bemoeiingen van Neumann Spallart, het Institut International de Statistique tot stand 1). De toenmalige president van de feestvierende Statistical Society, Sir Rawson W. Rawson werd voorzitter, in het vice-presidiaat werden benoemd Neumann Spallart en Levasseur, terwijl met het secretariaat de Directeur-Generaal der Italiaansche statistiek, Lujgi Bodio werd belast.

Iedere twee jaren zou het Institut in algemeene zitting bijeenkomen, en tot dusver hebben deze zittingen ook inderdaad regelmatig plats gehad: te Rome (1887), Parijs (1889), Weenen (1891), Chicago (1893), Bern (1895) en St. Petersburg (1897). In deze bijeenkomsten heeft het Institut zich niet bepaald tot de wetenschappelijke behandeling van hetgeen strekken kan om het gebied der statistiek uit te breiden, en hare bewerking te doen geschieden volgens methoden, welke de internationale vergelijkbaarheid van hare uitkomsten konden verzekeren; het heeft ook zelf internationale onderzoekingen op touw gezet of uitgelokt. Zoo de internationale statistiek van het lager onderwijs, die van het roerend vermogen, die van de oppervlakte en de bevolking der aarde warrvan een nieuwe uitgaaf

1) Voor Nederland kregen zitting als eereleden Prof. S. Vissering en Mr. N. P. van den Berg, als gewone leden Prof. A. Beaujon en Mr. J. L. de Bruyn Kops, en als membre associé Mr. N. G. Pierson. In 1887 werd de onderscheiding tusschen membres titulaires en associés opgeheven, en het aantal membres titulaires op 150 bepaald. Uit ons land werden in de zitting van 1895 nog tot membre titulaire benoemd Mr. W. A. baron van Verschuer en Mr. W. A. P. Verkerk Pistorius en in de zitting van 1899 de ondergeteekende. 
voor 1900 wordt voorbereid, terwijl ouk het belangrijk muntrapport dat de heer de Foville in de laatste jaren uitbrengt, en met zoo volledig mogelijke internationale overzichten van de productie en het verbruik van de edele metalen verrijkt, aan een wensch van het Institut zijn ontstaan dankt. Bovendien bevatte het Bulletin, dat op ongeregelde tijden het licht ziet, nevens de verslagen van de zittingen van het Institut, menige bijdrage die tot het beste behoort wat op statistisch gebied in den laatsten tijd geschreven is.

Dat zijn "besluitelı" nopens de groudslagen en de wijze van bewerking der verschillende statistieken veelal goede vruchten gedragen hebben, kan, om uit meerdere één voorbeeld te kiezen, blijken uit de hervorming die de gerechtelijke statistiek in de laatste jaren in verschillende landen heeft ondergaan.

Zoo kon dan de heer Levasseur, die bij afwezigheid van den president Sir Rawson, door ziekte verhinderd om tegeuwoordig te zijn, de jongste zitting van het Institut opende, met voldoening terug zien op de eerste vijf lustra van deze nuttige instelling, en met grond de beste verwachting uitspreken voor haar toekomst.

Op uitnoodiging van het Noorsche gouvernement vergaderde het Institut ditmaal van 4-9 September te Christiania, en het feit dat, waar de georganiseerde bevolkingsstatistiek in de meeste overige staten eerst in den loop dezer eeuw is aangevaugen, de statistiek van den loop der bevolking in dit land tot 1734, de volkstellingen tot 1769 teruggaan, gaf an de Noorsche statistici zeker een bijzondere aauspraak, om hun collega's aan den vooravond der seculaire volkstelling uit te noodigen hun bijeenkomst in de hoofdstad van Noorwegen te houden.

De zitting kan over het geheel als volkomen geslaagd worden beschouwd. Ongetwijfeld had de opkomst der leden talrijker kunnen zijn, en met name miste men ook in deze zitting weder de vertegenwoordigers der Duitsche ambtelijke statistiek. Maar velen der besten waren gekomen en er is veel en goed gewerkt. Van de leden van het Institut waren er 36 verschenen waaronder 23 die het ambt bekleedden, of vroeger bekleed hadden van directeur of onderdirecteur van een bureau van statistiek. Bovendien waren een aantal statistici die geen deel van het Institut uitmaakten uitgenoodigd de zitting bij te wonen, of 
door hun regeering daarheen afgevaardigd, zoodat in het geheel een vijftigtal personen de vergadering bijwoonde.

Nadat de zitting den 4, ${ }^{\text {en }}$ September in de Aula der Universiteit door deu Minister van Binuenlandsche Zaken Qvam was geopend, en de heer Kiaer den leden en genoodigden een hartelijk welkom had toegeroepen, werd de vergadering in twee secties, eene gewijd aan de demographie, de andere aan de econoınische statistiek, gesplitst. Een wensch van den heer von Mayr om voor de gerechtelijke statistiek, die ten einde het antal secties niet noodeloos te vergrooten in de eerste sectie was ondergebracht, eene afzouderlijke sectie te vormen, vond geen bijval. Gelukkig, immers waar de vergadering uit enkel vakmannen in den engen zin des woords bestond, waren eigenlijk alle onderwerpen op de agenda voor allen van belang en viel het dus reeds te betreuren dat praktische overwegingen tot het vormen van twee, in den regel gelijktijdig vergaderende, secties hadden geleid. In de demographische sectie werd de heer von Mayr voorzitter, terwijl in de economische de drie vice-presidenten van het Institut en de heer Kiner afwisselend den voorzitterstoel bekleedden. De secties hebben gedurende vier dagen vergaderd, in den regel 's morgens van $10-12$; bovendien hield de demographische sectiẹ den laatsten dag nog een extrazitting ter behandeling der voorstellen van Prof. Rauchberg in zake de beroeps- en bedrijfstellingen. In den middag werden algemeene vergaderingen gehouden bestemd voor de behandeling van onderwerpen van meer algemeen belang en voor de huishoudelijke aangelegenheden van het Institut.

Vijf dagen waren aldus voor den arbeid bestemd, terwijl de Vrijdag werd gewijd aan eene excursie naar het schilderachtige Drammen Toch hadden de gastvrije Noren zich niet door het uitgebreid werkprogram laten weerhouden om door verschillende feesten te doen blijken van hun ingenomenheid met de komst van het Institut in hun hoofdstad. En al mogen de feesten zeker bij vergaderingen als cleze niet op den voorgrond staan, toch schuilt er waarheid in hetgeen de heer Levasseur in zijn openingsrede zeide: "qu'elles sont cependant une partie intégrale des réunions scientifiques internationales, et une partie non seulement agréable mais véritablement utile. Les séauces mettent en contact les idées et les savants; les fêtes rapprochent 
les hommes; de collègues elles font des amis." De koning "was hierbij voorgegaan, door, nadat hij aan het Institut en zijn genoodigden nog vóór de opening van de zitting een bịjzondere audientie had verleend, hen later aan een diner te vereenigen. De stad Christiania bood harerzijds aan het Institut een schitterenden maaltijd aan; de heer Kiaer noodigde, op zijn bekoorlijke villa te Hövik, zijn collega's een middag in den zoo sympathieken kring van zijn geziu, en het comité vau organisatie bood het Institut in het paleis der Loge een afscheidsdiner an. Wat mij betreft mag ik niet nalaten met warme erkentelijkheid hier te vermelden de schitterende ontvangst mij door onzen Consul-generaal den heer O. E. Kiaer den laatsten dag van mijn verblijf te Chistiania in zijue aau de fjord prachtig gelegen gastrrije woning bereid.

$\mathrm{Bij}$ de vermelding van het verhandelde in de onderscheiden vergaderingen wensch $\mathrm{ik}$ eerst elke der beide secties, en daarna de algemeene vergaderingen te bespreken.

De Demographische sectie opende hare beraadslagingen met een rapport van Bertillon over de mate waarin zijn, op uitnoodiging van het Institut, ontworpen voorstel tot uniformeering der classificatie van de doodsoorzaken in de sterftestatistiek, reeds door verschillende regeeringen was aanvaard. Niet alleen Noord-Amerika, Mexico en verschillende $Z$. A merikaansche Staten, hebben zich net zijn classificatie vereenigd, ook in Europa is dit reeds het geval met Frankrijk, Wurtemberg en Griekenland, en voorts met verscheiden groote steden, terwijl in een aantal andere landen de zaak of in studie is of wel geneigdheid bestaat deel te nemen aan de in 1900 te Parijs te loouden conferentie, waarin de aanvankelijke classificatie zal worden herzien. Ik kon mededeelen dat ook in ons land de zaak in onderzoek is, al moest ik daardoor ook de illusie van Bertillon, die door een misverstand meende, dat zij reeds geheel beklonken was, komen verstoren. Von Körösy had tegen de details van het plan verschillende bedenkingen ontwikke?d in eene vooraf rond gezonden brochure. ') De discussie daarover was echter zeer terecht in deze bijeenkomst van niet-

1) Zur internationalen Nomenclatur der Todesursachen. Berlin, Puttkammer \& Mühlbrecht. 
medici, door Bertillon afgesneden, daar zijn voorstel, waarmede sectie en plenum zich vereenigden, niet verder ging dan een aanbeveling "en principe et sauf révision" van het plan zooals dit door hem ontworpen was.

Von Körösy herinnerde aan de besluiten in vroegere zittingen genomen nopens het kader voor de bewerking der volkstellingen en stelde voor deze met het oog op de seculaire telling thans, nu het nog tijd was, bij wege eener circulaire in herinnering te brengen bij de bureaux voor statistiek met de bewerking belast. De heer Moron maakte voor Frankrijk reserves voor wat aangaat de godsdiensttelling waartoe de conseil supérieur de statistique niet wil besluiten, uit vrees daarmede te raken ... aan de godsdienstvrijheid. En de heer Baines trachtte de Engelsche praktijk met betrekking tot de telling der bevolking naar den leeftijd, waarbij de bevolking niet naar levensj a ren maar naar leeftijdsg roepen onderscheideu wordt, te verdedigen, waarbij hij echter geen steun vond. De vrees voor opzettelijk onjuiste opgaven bij de leeftijden omstreeks 20,30 jaar enz. vindt toch in de werkelijkheid geen bevestiging, althans niet in voldoende mate oin afstand te doen van de enorme voordeelen, wetenschappelijke zoowel als praktische, welke een depouillement der gegevens voor ieder levensjaar afzonderlijk biedt. Het voorstel van Körösy werd ten slotte aangenomen en is thans door het bureau van het Institut reeds uitgevoerd.

Door von Körösy werden voorts, in aansluiting aan hetgeen in de Berner zitting van het Institut ter zake was verhandeld. ontwerpen ter tafel gebracht voor de uniforme bewerking der statistiek van deu loop der bevolking, voorloopig nog alleen die der geboorten. Gelijk alles wat von Körösy ter hand neemt, was ook deze zaak zeer grondig door hem voorbereid, onder meer door de bewerking van een synoptisch overzicht der wijze waarop thans de statistiek der geboorten in de verschillende landen is ingericht. Zijn voorstellen werden dan ook aangenomen.

De uitgave van het vroeger reeds gevoteerd internationaal jaarboek der bevolkingsstatistiek stuit voorloopig nog af op de schaarschte van geldmiddelen waarmede het Institut te worstelen heeft.

In de tweede zitting dezer sectie was het eerst von Inama 
Sternegg aan het woord over de armenstatistiek. Mischler, die over hetzelfde thema een voordracht had aangekondigd, was niet tegenwoordig, zoodat door het speciale comité in Petersburg benoemd voor de statistiek van het armwezen, welks rapporteur Mischler was, geen rapport kon worden uitgebracht. Von Inama Sternegg vestigde, in verband met een onlangs van zijn hand verschenen statistiek van de "persönliche Verhältuisse der Wiener Armen", in het bijzonder de aandacht op de gebrekeu van dat deel der statistiek van het armwezen hetwelk de bedeelden betreft. In de genoemde brochure heeft Von Inama de gegevens waarover de in 1880 opgerichte en van den aanvang af door hem gepresideerde Verein gegen Verarmung und Bettelei in Wien, de grootste particuliere vereeniging op dit gebied in Oostenrijks hoofdstad, beschikt met betrekking tot de armen die zich in den loop van haar bestaan tot haar wendden om hulp, statistisch verwerkt. Nopens 40080 gevallen worden gegevens medegedeeld aangaande : geboorteplaats, geslacht, domicilie, verblijfsduur, burgerlijken staat, ouderdom, omvang der gezinnen, beroep, oorzaken der armoede, inkomen, huishnur en schulden. Bij pngingen om dergelijke onderzoekingen meer algemeen te maken, door ze uit te strekken tot de geheele gemeente, de provincie of het rijk stuit men op de gebreken der bedeeldenstatistiek welke ook in ons land herhaaldelijk zijn uiteengezet, en die alleen te ondervangen zijn door verband te brengen tusschen de verschilleude instellingen van armenzorg. De heer von Inama stelde daarom voor, in het belang van de ontwikkeling der statistiek van het armwezen, de invoering aan te bevelen van een centraal register van bedeelden, wat door den heer Mischler b.v. in Stiermarken reeds is tot stand gebracht.

Over dit voorstel ontspon zich een uitvoerige gedachtenwisseling, waarbij echter misverstand bleek te bestaan nopens den aard van dit register, gevolg wellicht van de door von Inama min gelukkig gekozen naam, toen hij sprak van "cadastre des indigents". Geen blijvend kadaster van armen wordt er mede bedoeld, dat voor statistische doeleinden een twijfelachtige waarde zou bezitten, ook al ware het practisch uitvoerbaar, maar zooals Bodio het nader omschreef: "il faut que toutes les institutions publiques de charité se communiquent réciproquement", - liefst, gelijk von Mayr er bij voegde, in een 
voor dit doel geschapen "centre neutre" - les renseignements qu'elles possèdent sur les personnes secourus pendant. l'année. Het was mij aangenaam, na een korte schets van den aard en de geschiedenis onzer eigen armenstatistiek, een der oudste die bestaan, te kunnen mededeelen dat op invoering van zoodanig register als het eenig middel ter verkrijging eener juiste bedeeldenstatistiek door de Centrale Commissie voor de Statistiek in haar ter zake uitgebracht advies was gewezen, en mij geheel bij het voorstel van den heer von Inama, dat ten slotte aangenoinen werd te kunnen aansluiten. Moge de aanstaande herziening onzer armenwet ons dit register brengen, al ware het voorloopig nog slechts in de grootere gemeenten, waar de behoefte daaraan zich ongetwijfeld het sterkst doet gevoelen.

In dezelfde zitting deelde de heer Turquan, de gewezen directeur der Statistique Générale de la France, een uitvoerige studie mede, door hem gewijd aan de vruchtbaarheid der huwelijken in verband met den leeftijd der beide ouders in Frankrijk. Doel van zijn mededeeling was, de door hem gevolgde methode aan te bevelen voor de landen (resp. steden) waar, bij gebreke eener rechtstreeksche telling der echtparen met onderscheiding van den leeftijd der beide echtgenooten, vruchtbaarheids-berekeningen slechts benaderenderwijze mogelijk zijn. Noodig is daarvoor te kenuen den leeftijd van de ouders op het tijdstip der geboorte hunner kinderen, de sterftekansen van beide geslachten naar den burgerlijken staat, en de bevolking naar geslacht, leeftijd en burgerlijken staat op het moment der volkstelling. Aangezien echter door het lnstitut bezwaarlijk ountrent methoden die bij wetenschappelijke onderzoekingen gevolgd behooren te worden bindende besluiten kunnen worden genomen, werd besloten zich er toe te bepalen op het onderzoek vau den heer Turquan, dat door talrijke diagrammen en geprojecteerde stereogrammen werd toegelicht, de andacht te vestigen.

De zitting van Woensdag werd geopend met een beschouwing vall den heer Sundbärg (Stockholm) over de methode om bij vergelijkende sterfteberekeningen gebruik te maken van eeu standaardbevolking. Hij toonde aan dat, wanneer men groote bevolkingsgroepen neemt, allerwege de groep der 15- 
50 jarigen ongeveer de helft der bevolking omvat ') en dat verschillen in den opbouw der bevolking naar den leeftijd dus in hoofdzaak slechts de onderlinge verhouding der leeftijdsgroepen der $0-15$ jarigen en der personen van 50 jaar of ouder betreffen. Waar nu de gemiddelde sterfte (in de jaren 1871--80) in de germansche en romeinsche landen van Buropa is geweest voor den leeftijd van $0-15$ jaar $37,4,4 \%$, voor dien van $15-50$ jaar $9,93 \%$ oo en voor dien van 50 jaar en daarboven $47,91 \%$, concludeerde hij dat op het totale sterftecijfer de leeftijdsgroepeering niet zooveel invloed kan hebben als wel eens beweerd wordt, en dat dus de gebruikelijke sterftequotienten een bruikbare maat voor de sterfte opleveren. Het was te verwachten dat von Körösy, de geestelijke vader van die standaardberekeningen, in deze eischen niet zonder meer zou berusten. De inleider erkende trouwens later zelf, dat wat voor groote bevolkingscomplexen (en dan nog maar tot op zekere hoogte) waar is, voor kleinere bevolkingen en voor meer gedetailleerde sterfteberekeningen niet geldt. Er was dan ook geen aanleiding voor het Institut om op zijn aanbeveling van de standaardberekeningen terug te komen.

De heer Kiaer had een belangrijk vraagpunt aan de orde gesteld, te weten hetgeen door het Institut gedaan kon worden ter verkrijging van betrouwbare gegevens omtrent den stand en den opbouw der berolking in die streken der aarde waar nog geen geregelde volkstellingen hebben kunnen plaats grijpen. Hij beval daarvoor aan het volgen van de representatieve methode van onderzoek, welke voor zooveel aangaat de koloniën en invloedssfeeren der onderscheidene mogendheden, voor rekening van deze, zou moeten worden toegepast door hare administratieve organen, en eventueel door reizigers en zendelingen. Voor het dan nog overblijvend deel der aarle zou hij een internationaal bureau, door een overeenkomst der toetredende staten gewaarborgd voor een tijdvak van ten minste 5 jaren, wenschen in het leven geroepen te zien, voor de tot standkoming waarvan het Institut, dat bovendien bij de vitvoering zijn bijstand zou kunnen verleenen, het initiatief zou moeten nemen. De

1) Het maximum wordt in Zuid-Amerika gevonden (509\% \%), het minimum in Noorwegen $(484 \%$ \% $)$. 
kosten werden geraamd voorloopig niet meer dan 100.000 francs te zullen bedragen per jaar.

Het groote wetenschappelijk belang dezer aangelegenheid vond algemeene erkenning. De deınographie der niet beschaafde volken is nog zoo goed als geheel te schrijven. Isn niet alleen een wetenschappelijk belang is er bij betrokken. Onderzoekingen als hier bedoeld raken evenzeer materieele belangen van groot gewicht. Bestond er dus op dit punt geen verschil van iuzicht, de zaak kwam toch in de discussiën welke het voorstel volgden te weinig voorbereid voor, om reeds in deze zitting een besluit te provoceeren. Met instemming van den heer Kiaer werd zij daarom commissoriaal gemaakt, en de beslissing tot de volgende zitting van het Institut aangehoudeu.

De vergadering van Donderdag was geheel gewijd an de crimineele statitiek. De discussiën werden ingeleid door Bodio die aan de hand der ervaringen in Italie verkregen met de persoonskaarten als grondslag voor de crimineele statistiek, de invoering en de gecentraliseerde bewerking daarvan anbeval aan de landen waar tot dusver nog op de vroegere wijze de statistiek wordt bewerkt. De Italiaansche bulletins, die door Bodio beknoptelijk werden toegelicht, onderscheiden zich in tweeërlei opzicht van die elders in gebruik. In de eerste plaats worden zij angelegd zoodra een misdrijf wordt vervolgd. Nevens bijzonderheden omtrent den beklaagde (resp. veroordeelde) bevatten zij daarom een volledig overzicht van de behandeling van zijn zaak, eindigend met de veroordeeling (resp. vrijspraak of ontslag) en de eventueele wijziging in de uitspraak gebracht na hooger beroep of appel in cassatie. En in de tweede plats worden telkaarten ook aangelegd voor misdrijven warvan de daders onbekend bleven.

Bij de discussie verdedigde Prof. Tarde met eenige warmte de in Frankrijk gevolgde praktijk der gedecentraliseerde bewerking, voor welk standpunt hij intusschen geen steun vond. Evenals ik met betrekking tot ons land kon mededeelen is ook in Denemarken, waar onlangs de gerechtelijke statistiek geheel is gereorganiseerd, het beginsel der centralisatie van de kaarten aangenowen, en ook daar is men over de werking daarvan aanvankelijk zeer voldaan.

De heeren Prof. Bosco uit Rome en Prof. Tarde uit Parijs EcoN. 1899. 
deden vervolgens, de laatste aan de hand van een aantal kaauten en diagrammen, eenige mededeelingen omtrent den loop der criminaliteit in de verschillende landen van Europa in de laatste jaren. De behandeling van de statistiek der criminaliteit van kinderen, waaromtrent door de heereu d'Albanel en Raseri rapporten waren aangekondigd, bleef achterwege daar de auteurs verhinderd waren tegenwoordig te zijn.

In een buitengewone zitting der sectie werden ten slotte, in eene discussie welke drie uren duurde, uitvoerig besproken de ontwerp-besluiten nopens de beginselen welke aan beroepstellingen ten grondslag moeten liggen, door Prof. Rauchberg (Praag) aan de vergadering voorgelegd. Het desbetreffend referaat van Rauchberg was anvankelijk min gelukkig op de agenda eener plenaire samenkomst gebracht, waar weinig gelegenheid bestond tot eene grondige bespreking. Toen daar nu, nadat Rauchberg zijn stellingen had toegelicht, bleek dat er weinig geneigdheid bestond ze zonder meer an te nemen, werd op voorstel van von Mayr besloten de zaak vooraf nog in de demographische sectie te behandelen.

De panten waaromtrent Rauchberg een beslissing van het Institut wenschte uit te lokken waren de volgende: $1^{\circ}$ de beroepsstatistiek moet de geheele, werkelijke bevolking omvatten; de gezinsleden en dienstboden moeten worden gegroepeerd naar het beroep (resp. positie daarin bekleed) van den verzorger (resp. meester) in wiens gezin zij leven; $2^{\circ}$ voor de in eenig beroep werkzame personen moet beroep en positie daarin worden onderscheiden zoowel voor boofdberoep als voor nevenberoepen; $3^{\circ}$ de groepeering der bevolking naar het beroep moet geschieden op grond van het beroep persoonlijk door ieder uitgeoefend; het beroep der werkgevers moet alleen gevraagd worden ter juister omschrijving van het persoonlijk beroep der arbeiders; 4.0 bovendien is het wenschelijk aan de in loondienst werkzamen ook de naam (firma), het adres, en het bedrijf van hun werkgevers te vragen en wel $a$. als controle middel van hun eigen beroepsopgave; $b$. in het belang eener combinatie van hun persoonlijk beroep met de tak van bedrijf waarin het wordt uitgeoefend; $c$. als hulpmiddel voor een werkloozenstatistiek; $5^{\circ}$ het is wenschelijk met de beroepstelling eene bedrijfstelling te verbinden en de gegevens bij deze laatste 
verzameld ook beroepsstatistisch te gebruiken ten einde zoodoende de sociale positie der patroons scherper te caracteriseeren.

In verschillend opzicht lokten deze voorstellen bestrijding uit. Door Bertillon en Baines werd bezwaar gemaakt tegen de opneming van de dienstboden, die een zelfstandig beroep uitoefenen, onder de gezinsleden. Mij aansluitend bij deze oppositie moest $\mathrm{ik}$, voor wat Nederland aangaat, bovendien mededeelen dat de a. s. beroepstelling niet geheel aan de wenschen van Rauchberg zou beantwoorden. De "berufsangehörige" zullen, tot mijn leedwezen moet ik er bijvoegen, ook ditmaal weder in én groep met de personen zonder beroep worden gerangschikt. En wat de nevenberoepen betreft, ten einde de beroepstelling, die blijkens de ervaring van 1889 in de praktijk nog op tal van bezwaren stuit, niet te compliceeren, zal daaruaar ook bij de aanstaande telling nog geen vraag worden gedaan.

legen de punten sub 3 en 4 genoernd bestond overigens bij mij geen bezwaar; wel tegen de overwegingen van het vierde punt. De tweede overweging kwam mij voor, de grens tusschen beroeps- en bedrijfstelling uit het oog te verliezen, en de derde scheen mij geheel onbegrijpelijk. Prof. Rauchberg had hem aanvankelijk toegelicht in dien zin, dat alle in loondienst werkenden, die geen naam konden opgeven van hun patroons, als werkloos zouden gelden. Het is echter gemakkelijk in te zien, dat dit volstrekt ongeoorloofd zou wezen, al ware het slechts omdat zoodoende alle losse werklieden met één slag werkloos zouden heeten. De heer Rauchberg gaf later toe, dat men aan hen, die door het onbeantwoord laten der vraag naar de patroons werkloos zouden schijnen, nog speciale vingen zou moeten stellen, en verklaarde zich op mijn verzoek bereid het vierde punt en de overwegingen afzonderlijk in stemming te brengen. Het punt zelf werd daarna aangenomen, de overwegingen echter verworpen.

Eene vrij verwarde discussie over de wijze waarop hoofden nevenberoep gecombineerd zouden worden in het tabelwerk ${ }^{1}$ )

1) De bedoeling was natuurlijk niet alle hoofdberoepen met alle nevenberoepen in verbinding te brengen; de vraag naar het nevenberoep beoogt drieërlei: $1^{\circ}$ bij ieder hoofdberoep de beoefenaars te onderssheiden in hen die wel en hen die niet een nevenberoep 
was oorzaak dat voor eene grondige discussie van het vijfde punt de tijd ontbrak. Nadat de heer Rauchberg nog de dienstboden uit het eerste punt had moeten weglaten, werden ten slotte zijn conclusiën aangenomen.

Inde economische sectie was het eerst de heer Bateman aan het woord, die een nader rapport uitbracht over de vergelijkbaarheid der handelsstatistieken in de verschillende landen, daarbij in het bijzonder wijzende op de verschillen in de wijze waarop de doorvoer, en de handelsbeweging in de vrijhavens zooals Hamburg en Copenhagen, behandeld wordt. Aan de discussie over dit onderwerp, waarbij getracht werd een juiste grens te trekken tusschen de commerce spécial en général, namen deel de heeren Lexis, Levasseur, von Inama, 'Tisserand Sir R. Giffen en de Foville. De grens is echter moeilijker te trekken naarmate een land minder artikelen met invoerrechten heeft belast. Besluiten werden uiet genomen, en geen andere wenschen geformuleerd dan deze, dat ieder die internationale vergelijkingen wenscht te maken aan de hand der handelsstatistieken, zich vooraf behoort op de hoogte te stellen van de beteekenis gehecht aan de termen welke daarin worden gebezigd, een weusch welken ongetwijfeld ieder deelen zal.

De heer Blau (Petersburg) deed belangrijke mededeelingen nopens de pogingen in Rusland in den jongsten tijd gedaan tot verbetering van de statistiek der prijzen van handelsartikelen.

Stuit men bij de bewerking en onderlinge vergelijking der handelsstatistieken van den tegenwoordigen tijd op groote moeilijkheden, gelijk de heer Bateman had betoogd, de bezwaren vermenigvuldigen zich wanneer men over de handelsbeweging in vroeger eeuwen gegevens wil verzamelen. Prof. Stieda (Leipzig) hield over dit onderwerp een voordracht, waarin hij de beteekenis voor dit doel uiteenzette van de tolregisters, de scheepvaartregisters, de koopmansboeken en de berichten over scheepsrampen welke in de archieven berusteu. Er is op dit gebied reeds een en ander in het licht gegeven,

uitoefenen $2^{\circ}$ eventueel van alle denkbare nevenberoepen het landbouwbedrijf telkens afzonderlijk te vermelden $3^{\circ}$ voor ieder beroep met juisthejd op te geven het aantal personen dat het, zij het dan als hoofd- of als nevenberoep, vitoefent. 
maar gelijk Prof. Stieda, met voorbeelden van voudsten door hemzelf gedaan en waarvan hij eerlang uitvoeriger verslag hoopt te doen nader toelichtte, ligt er in de archieven nog veel verborgen wat ten volle verdient publiek gemaakt te worden. De heer Levasseur vulde de mededeelingen van Prof. Stieda aan, met de vermelding van hetgeen in Frankrijk op dit gebied is gepubliceerd.

De zitting waarin door de heeren Levasseur en Craigie de landbouwstatistiek werd behandeld, kon ik niet bijwonen.

In hare zitting van Woensdag behandelde de economische sectie de financieele statistieken. Het Institut had in 1895 te Bern op voorstel van den heer Kümmer en van Prof. Ferrari eenstemmig aangenomen een motie strekkende "que le Gouvernement Francais veuille bien mettre l'administration compétente à même de publier périodiquement un document statistique ayant pour objet la production des métaux précieux, leur mouvement international et la consommation de l'or et de l'argent dans les divers Etats (emploi industriel, monnayage, frais)." De Fransche regeering heeft zich gehaast aan dezen wensch te voldoen, en reeds in 1896 den eersten jaargang doen verschijnen van een rapport door den directeur van de Munt, den heer de Foville, bewerkt, waarin hoogstbelangrijke internationale statistieken vau het verbruik en de voortbrenging der edele metalen ziju opgenomen en dat zich spoedig naast de Engelsche en Amerikansche muntverslagen in een groote mate van gezag bij hen die zich met het muntvraagstuk bezig houden mocht verheugen ${ }^{1}$ ). De heer de Foville kon aan de vergadering thans den belangrijk uitgebreiden vierden jaargang overleggen. Prof. Lexis vestigde naar aanleiding hiervan de aandacht der vergadering op het feit, dat er tusschen de cijfers van de zilverproductie en de zilverconsumtie eene marge ligt die zou doen vermoeden, dat ergens eeu tot dusver onbekend gebleven, doch van jaar tot jaar angroeiende zilvervoorrad bestaat. De heer de Foville antwoordde dat omtrent het verbruik van zilver nog geeu volledige gegevens bekend zijn, maar dat de statistiek, gelijk ook zijn rapport bewijst; in dit opzicht langzaam de volledigheid nadert.

1) Zie de bespreking van dit rapport door den heer G. M. Boisserain in de Economist van 1896 bladz. 857. 
In dezelfde zitting van het Institut was aan een commissie opgedragen te onderzoeken op welke wijze het best eene internationale statistiek van het roerend vermogen en de rente die het afwerpt zou kunnen worden verzameld. De heer Neymarck, rapporteur van deze commissie, kon mededeelen dat deze statistiek thans in een aantal landen verzameld wordt, en dat, ofschoon nog verre van compleet, toch uitzicht bestaat dat zij het eerlang zal kunnen worden. De cijfers tot dusver door hem verzameld werden aan het Institut overgelegd, dat het mandaat van het comité en zijn rapporteur verlengde.

De heer Fernand Faure rapporteerde namens de commissie belast met de bewerking van een internationaal vergelijkend overzicht der fiscale lasten die op bet roerend vermogen drukken. Ook dit overzicht omvat nog niet alle landeu, maar hetgeen tot dusver blijkens de mededeelingen van den heer Faure is verzameld, werd door het Institut van genoeg belang geacht om ook het mandaat dezer commissie te verlengen. In verband met deze beide rapporten werd op voorstel der heeren Neymarck en Moron door het Institut besloten $1^{\circ}$ eene internationale statistiek te bewerken van de belastingen die op de handels- en nijverheidsbedrijven in de verschillende landen drukken; $2^{\circ}$ te onderzoeken in hoeverre deze belastingen onderling vergeleken kunnel worden en welk hare beteekenis is en $3^{\circ}$ dit onderzoek zooveel mogelijk monographisch te doen geschieden, aan de hand van enkele bepaalde typen van vergelijking.

Door de beeren Borkowsky (Petersburg) en de Swarte werdeu in eene vergadering dezer sectie die ik verhinderd was bij te wonen mededeelingen gedaan omtrent de wijze van bewerking der statistiek van het goederenvervoer te water, en omtrent eeue uit de archieven bewerkte statistiek van de Fransche schat. kist in de $18^{\mathrm{e}}$ eeuw.

Voorbijgaand hetgeen in de plenaire vergaderingen werd verhandeld met betrekking tot de huishoudelijke aangelegenheden van het Institut, dient nog het een en ander te worden medegedeeld over de voordrachten welke in deze zittingen gehouden werden. De heer Tröinitzky, die het reuzenwerk der russische volkstelling leidt, deed daaromtrent interessante mededeelingen in aansluiting aan hetgeen in St. Petersburg in 1897 ter zake was verhandeld. Op het oogenblik werken, ofschoon de controle 
en het overbrengen der gegevens op de telkaartjes voor de electrische telmachines (waarvan er 10 in gebruik ziju, ieder ter waarde van ongeveer $f 40.000$ ) goeddeels reeds is afgeloopen, nog 1300 ambtenaren aan de bewerking der vitkomsten dezer telling en laat het zich aanzien dat nog een drietal jaren zal moeten verstrijken voor zij geheel gereed zullen zijn. De kaders der verschillende tabellen werden door den heer Tröinitsky toegelicht en de eerste resultaten der telling, voor enkele gouvernementen, aan de vergadering medegedeeld.

Over een nieuwe bewerking van de statistiek der oppervlakte en der bevolking van de aarde in 1900 , en over de internationale statistiek van het lager onderwijs, waarvan de drukproeven ter tafel lagen, deed de heer Levasseur enkele mededeelingen.

De heer Bateman gaf een overzicht van de uitbreiding welke het arbeidsveld van het Conmercial, Labor and Statistical Department of the Board of Trade, dat na het aftreden vau Sir R. Giffen onder zijn leiding is gekomen, in de laatste jaren heeft ondergaan, en waarvan de vruchten allerwege met groote erkentelijkheid zijn ontvangen.

Prof. Fahlbeck uit Lund leverde eene interessante studie over de demographie van den Zweedschen adel. Zijne onderzoekingen leverden 0 . a. een sterftetafel der adelijke geslachten daar te lande, volgens welke van 1000 geslachten behoorende tot den lageren adel na 100 jaar nog 4.31 , na 150 jaar nog 309 , na 200 jaar nog 237 bestaan. Voor den hoogeren adel ging zijn tafel niet verder dan 150 jaar terug; van 1000 geslachten van deze categorie bestonden er na 100 jaar 537 , en na 150 jaar 398 De oorzaken dezer suelle afsterving zocht Fahlbeck in de afnemende nuptialiteit en huwelijksvruchtbaarheid welke hij had waargenomen. 'Zoo bedroeg in verhouding tot alle meerderjarige mannelijke leden der zweedsche adelijke geslachten van vijf generaties oud, het percentage der gehurde mannen: in de tweede generatic 70 pCt., in de derde 62.96 , in de vierde 60.65 , en in de vijfde nog slechts 28.77 pCt.; en de huwelijksvruchtbaarheid (te weten het gemiddeld aantal in de vruchtbare huwelijken lev nd geboren kinderen) in deze geslachten: bij de eerste generatie 5.57, bij de tweede $\mathbf{5 . 4 6}$, de derde 3.85 , de vierde 3.51 en de vijfde 2.67 . Daarbij komt dan nog de toenemende inortaliteit op jeugdigen leeftijd naarmate de ge- 
slachten ouder worden; immers bedroeg in verhouding tot alle mannen van $0-19$ jaar de sterfte in deze leeftijdsgroep bij de genoernde geslachten: in de tweede generatie $17.57 \mathrm{pCt}$. , in de derde 34.15 , in de vierde 40.84 en in de vijfde 4.3 .41 .

De heer Swarte legde een statistiek over de ontwikkeling der Bibliothèque nationale te Parijs en van het gebruik van haar gemaakt sedert het begin dezer eeuw aan de vergadering voor, hetgeen het Institut aanleiding gaf om, op voorstel van den beer Neymarck, den wensch uit te spreken, dat in de groote boekerijen eene statistiek van de aanwezige en de geraadpleegde boeken, in eenige groote categoriën gegroepeerd, zou worden gemaakt en geregeld bijgehouden.

Door mij werd een overzicht gegeven van de ontwikkeling en reorganisatie onzer ambtelijke statistiek, aanknoopend aan het referaat van wijlen Prof. Beaujon in 1885 gehouden ter $25^{\mathrm{e}}$ jaarvergadering van de Societé de Statistique de Paris.

Tijdens mijn verblijf te Christiania bereikte mij het bericht van het overlijden van den heer Verkerk Pistorius, lid van het Institut. Ik veroorloofde mij hiervan aan de vergadering inededeeling te doen en in eene korte necrologie de nagedachtenis van den heer Pistorius, en zijne verdiessten voor de Nederlandsche statistiek te eeren. De heer Bateman sloot zich hierbij aan, herdenkend zijne eerste ontmoeting met den heer Pistorius ter Londensche suiker-conferentie, en hunne onderlinge samenwerking, ter ziting van 1895 te Bern, in het belang der internationale vergelijkbaarheid van de handelsstatistieken.

Ten slotte dient nog vermeld te worden dat verschillende statistici, op de vergadering tegenwoordig, ter gelegenheid der zitting van het Institut werken hadden het licht doen zien, waarvan an de deelnemers gedrukte exemplaren werden aangeboden. Zoo legde de heer E. Amnëus, assistent bij het Centraal Bureau voor de statistiek te Christiania, een belangrijk overzicht van den handel en scheepvant dezer stad over. De vertegenwoordiger van bet Japansche gouveruement, graaf Yanagisawa, werkzaam in het Centraal Bureau te Tokio, deelde eene memorie mede over de ontwikkeling der statistiek in Japan, en de heer Fontell onder-directeur van het statistisch bureau te Helsingfors eene uitgebreide statistiek van den loop der bevolking in het groothertogdom sedert 1750 . 
In de laatste algemeene vergadering werd overgegaan tot de benoeming van een nieuw bestuur. De grijze Sir Rawson W. Rawson die reeds tweemaal had verzocht van het presidiaat te worden ontheven, doch telkeus voor den aandrang der leden om op zijn post te blijven was gezwicht, had ditmaal zijn stellig verlangen kenbaar gemaakt niet herkozen te worden. Als een rechtmatige hulde aan zijn verdiensten werd hem het eere-voorzitterschap aangeboden. De heer von Inama Sternegg w'erd in zijn plaats met groote meerderheid tot voorzitter voor de eerstvolgende twee jaren benoemd. Ne drie onder-voorzitters Levasseur, Lexis en Tröinitzky werden herbenoemd evenals de penningmeester Bateman, en de secretaris-generaal Bodio. Als plaats waar in 1901 de volgende zitting zal worden gehouden werd op uitnoodiging van het Hongaarsche gouvernement Budapest angewezen.

Zoo was in deze zitting van het Institut op velerlei gebied van gedachten gewisseld, over onderwerpen van statistisch belang. In deze onderlinge wisseling van denkbeelden in en buiten de vergaderingen, van persoon tot persoon in een betrekkelijk kleinen kring kan niet anders dan goede vruchten dragen voor de ontwikkeling der statistiek. Men leert elkander beter kennen en begrijpen, bedoelingen en methoden, die uit de gedrukte bescheiden niet aanstonds voor zich zelve spraken, waardeeren, en knoopt banden aan die blijveude beteekenis hebben. Met het volste recht mocht dan ook de heer Levasseur, die oudanks zijn 71 jareu een uitmuntende en onvermoeibare leider was geweest onzer vergaderingen, in zijn sluitingswoord ziju voldoening uitspreken over het succes dezer bijeenkomst, die bij allen die haar mochten bijwoven ongetwijfeld in de aangenaamste herinnering zal blijven.

Den Haag, September 1899. C. A. VerriJn Studurt. 